\title{
Basidiobolomycosis in Togo: clinico-pathological study of a series of 12 presumed cases
}

Tchin Darré ${ }^{14^{*}}$, Bayaki Saka², Abas Mouhari-Toure ${ }^{3}$, Toukilnan Djiwa ${ }^{1}$, Palokinam Pitché ${ }^{2}$ and Gado Napo-Koura ${ }^{1}$

\begin{abstract}
Objective: The purpose of our study was to describe the histological diagnosed of the Basidiobolomycosis cases from 1990 to 2017 (28 years) in the only Pathology Anatomy Laboratory in Togo.

Results: A total of 12 cases of suspected Basidiobolomycosis have been identified. The sex ratio (M/F) was 2. The average age of the patients was $24.8 \pm 1.6$ years. Six patients (6/12) had a pathological history: HIV infection $(n=4$ cases) and tuberculosis ( $n=2$ cases). The clinical manifestations were localized to pure skin ( $n=9$ cases), skin and mucous digestive ( $n=2$ cases) and disseminated ( $n=1$ cases). Direct mycological examination and culture in 4 patients was positive in 3 patients. The samples examined consisted of 11 cutaneous biopsies measuring 1-3 cm and a biopsy of the intestinal mucosa. Histology showed granulomatous inflammation of the dermohypodermal site with numerous giant cells associated with eosinophilic polynuclear cells, in which there are 5-7 mm non-septate, irregular mycelial filaments. Patients were treated with ketoconazole at a dose of $10 \mathrm{mg} / \mathrm{kg}$ daily. The progression of the patients' condition was favorable after 4 weeks of treatment with a regression of the closets size. Patients were completely healed after 8 weeks of treatment, without recurrence after 6 months. No deaths have been recorded.
\end{abstract}

Keywords: Basidiobolomycosis, Basidiobolus ranarum, Histology, Togo, Sub-Saharan Africa

\section{Introduction}

Basidiobolomycosis is a rare deep mycosis found in rural areas in tropical areas, mainly in Africa, Asia and Latin America [1]. The main etiologic agents have Basidiobolus ranarum and Basidiobolus haptosporus, saprophyte of soil and plants of tropical and subtropical countries $[2,3]$. The diagnosis of Basidiobolomycosis is not easy because the clinical and histopathological signs do not point directly to a fungal infection and especially in the tropics where it can simulate a Mycobacterium ulcerans infection $[4,5]$.

Although medical treatment with oral potassium iodide and ketoconazole may be effective, untreated infection may be fatal [5]. In the past 40 years, 179 cases of Basidiobolomycosis have been reported worldwide [4-7]. It is a condition rarely described in Africa and its

\footnotetext{
${ }^{*}$ Correspondence: paolodarre@yahoo.fr

${ }^{4}$ University of Lomé, BP 1515, Lomé, Togo

Full list of author information is available at the end of the article
}

actual frequency is not known, most published studies being clinical cases $[2,4,7]$. In Togo, there have been 3 published clinical cases, but no serial study is done $[2,5$, 8]. This work brings together the cases of Basidiobolomycosis diagnosed in the laboratory of pathological anatomy of Lomé. It aims to clarify the epidemiological, diagnostic and therapeutic aspects of Basidiobolomycosis in Togo.

\section{Main text \\ Methods}

This was a descriptive study on all the records (registers and test reports) of histological diagnosed Basidiobolomycosis in the only Laboratory of Pathological Anatomy in Togo, from January 1990 to December 2017. During this period, the samples were recorded in the pathology laboratory register, prepared in fine sections embedded in paraffin $\left(56-60{ }^{\circ} \mathrm{C}\right)$ and then stained with haematin eosin (H.E). The results and review reports of all cases compiled from the registers were collected using a preestablished form. This study was approved by the head of 
the laboratory department of Sylvanus Olympio teaching Hospital ( $\operatorname{Ref} N^{\circ}$ 08/2017/LAP/CHUSO). During the counting and data collection patient names were not collected in order to preserve confidentiality.

\section{Results}

Twelve cases of Basidiobolomycosis were diagnosed including 8 men and 4 women. The average age of patients in our series was $24.8 \pm 1.6$ years, with extremes of 9 and 54 years old. All patients were from rural areas and of low socio-economic status: 9 patients were farmers and 3 students. Six patients $(6 / 12)$ had a pathological history: HIV infection was known in four patients and two patients 'was treated for tuberculosis. The clinical manifestations were localized to the skin in 9 cases, coetaneous and digestive mucous in 2 cases and disseminated form in 1 case. In the nine patients with pure skin localization, lesions were located in: lower limbs $(n=6$ cases, 4 on the thighs and 2 on the legs), buttocks and legs ( $\mathrm{n}=2$ cases), upper limbs $(\mathrm{n}=1$ case). The skin lesions were often an infiltrated closet, of firm consistency, with sharp edges, often measuring between $32 \mathrm{~cm}$ high and $15 \mathrm{~cm}$ wide. These closets were mobilizable compared to the deep planes and not painful to the palpation. There were no satellite lymphadenopathies. The general condition of the patients was preserved. Table 1 summarizes the sociodemographic characteristics of patients.

The direct mycological examination and culture performed in patients was positive in 3 days between them, with the detection of $B$. ranarum.

From the anatomopathological point of view, the samples examined consisted of 11 cutaneous biopsies measuring 1-3 $\mathrm{cm}$ and a biopsy of the intestinal mucosa. Histology had shown tuberculoid granulomas with giant cells, numerous lymphocytes, histiocytes, and

\section{Table 1 Epidemiological characteristics of patients}

\begin{tabular}{lc}
\hline Characteristics & Values \\
\hline Sex & \\
(i) Men & $8 / 12$ \\
(ii) Women & $4 / 12$ \\
Age (years) & \\
(i) Average & $24.8 \pm 1.6$ \\
(ii) Extremes & $9-54$ \\
Profession & \\
(i) Farmers & $9 / 12$ \\
(ii) Students & $3 / 12$ \\
Localization & \\
Skin & $9 / 12$ \\
Skin and mucosa & $2 / 12$ \\
Disseminated & $1 / 12$ \\
\hline
\end{tabular}

eosinophilic cells, an amorphous eosinophilic material also known as the Splendore-Hoeppli phenomenon, and septal hyphae fragments of $10 \mu \mathrm{m}$ in diameter.

Patients were treated with ketoconazole at a dose of $10 \mathrm{mg} / \mathrm{kg}$ daily. Hepatic transaminases were measured at the beginning of treatment and every 2 weeks during treatment. No hepatic intolerance was noted. The progression of the patients' condition was favorable after 4 weeks of treatment with a regression of the closets size. Patients were completely healed after 8 weeks of treatment, without recurrence after 6 months. No deaths have been recorded.

\section{Discussion}

Our study shows the extreme rarity of Basidiobolomycosis in Togo; however, it is one of the major series reported on this pathology. Microbiological confirmation by PCR for $B$. ranarum and culture provides the most accurate diagnosis, but they are not often available in endemic areas and with varying sensitivity. A combination of histopathological findings, granulomatous inflammation with giant cells, septate hyphal fragments and the Splendore-Hoeppli phenomenon, may confirm Basidiobolomycosis in patients with painless induration of soft tissues $[1,6]$.

Basidiobolomycosis is endemic in rural intertropical areas, particularly in Indonesia, Burma, India, and sub-Saharan Africa [2, 8]. The infection is caused by the filamentous fungus $B$. ranarum, belonging to the class zygomycetes and entomophthoral order [9]. Zygomycosis is an acute or chronic infection caused by fungal agents belonging to the phylum Zygomycota [9]. They are saprophytic fungi and are present in soil, decaying plant material and the intestines of amphibians, reptiles, fish and insectivorous bats [10]. The precise mode of contamination of $B$. ranarum is poorly known, but is thought to be transmitted through the skin after an insect bite, scratch or cut $[3,4]$.

The diagnosis of Basidiobolomycosis was histological suggested, based on the presence, namely granulomatous inflammation with giant cells, septate hyphal fragments and the Splendore-Hoeppli phenomenon, in patients with painless indurations' and hard soft tissue [11]. The differential diagnosis of Basidiobolomycosis includes soft tissue tumors, such as synovial sarcoma [11], Hodgkin's lymphoma [12], and mycetoma [13]. In addition, a tuberculoid granuloma with giant cells can also be observed in Buruli ulcer lesions, especially during healing $[7,8]$. However, neither septal hyphal fragments nor the Splendore-Hoeppli phenomenon are observed in Buruli ulcer lesions [8]. The Splendore-Hoeppli phenomenon itself is not specific for Basidiobolomycosis and can also be observed in other infections, such as bronchocentric 
granulomatosis due to Aspergillus [14], mycetoma [15] and cutaneous Pityrosporum folliculitis [16]. It is the combination of the clinical presentation, the Splendore-Hoeppli phenomenon and the compartmentalized hyphae that suggest Basidiobolomycosis [5, 14]. Cultivation of the $B$. ranarum fungus is difficult and clinical and histopathological features may help to suggest the diagnosis of Basidiobolomycosis [16, 17]. The detection of fungal pathogens by PCR is particularly difficult [17]. Fungal cell walls are not easily lysed for DNA release, leading to false negative PCR results [18]. Isolating $B$. ranarum DNA from formalin-fixed archival tissue blocks and paraffin embedded has been reported, with a protocol allowing reliable purification of fungal DNA [18].

The treatment of Basidiobolomycosis has been based for a long time on potassium iodide, which in most cases gives complete cures in 2-9 months $[1-4,19]$. However, the results with this drug are inconsistent. On four patients of the series of Ramesh et al. treated with potassium iodide, only two achieved complete remission after three and 9 months of treatment, respectively [20]. The other two patients, who showed only a simple regression, had to be put on ketoconazole for one, and on itraconazole for the other, to obtain complete remission [19]. In addition to the problem of inconsistent efficacy, this treatment has many side effects [21, 22]. Thus, Madke et al. reported the occurrence of hypothyroidism in a patient during the treatment of Basidiobolomycosis [23].

Azole derivatives have emerged as the treatment of choice for phycomycoses. Among them, ketoconazole has been shown to be effective in Basidiobolomycosis [5, $6,18]$. This imidazole has been used successfully for doses ranging from 5 to $10 \mathrm{mg} / \mathrm{kg} /$ day $[23,24]$. The duration of treatment for achieving complete cure ranges from 2 to 8 months $[24,25]$. No case of therapeutic failure has been reported so far with this antifungal, which has been well tolerated in all reported cases. In addition, none of the publications reported recurrence of symptoms, with periods of decline of 4 months and 11 years $[2-7,25]$.

\section{Limitations}

The mycological culture to identify the fungus was not done because of technical reasons.

\footnotetext{
Abbreviations

H.E: hematoxylin and eoisn; HIV: human immunodeficiency virus; PCR: polymerase chain reaction; DNA: deoxyribonucleic acid.
}

\footnotetext{
Authors' contributions

TD was responsible for the design of the study, undertook the field study, performed data collection, analysis, and interpretation, and wrote the manuscript. BS, AM, and TD participated in the design of the study, supervised the data collection, and participated in the data analysis. VPP and GN were responsible for the overall scientific management of the study, the analysis
}

and interpretation, and preparation of the final manuscript. All authors read and approved the final manuscript.

\section{Author details \\ ${ }^{1}$ Department of Pathology, University Teaching Hospital of Lomé, Lomé, Togo. ${ }^{2}$ Department of Dermatology, University Teaching Hospital of Lomé, Lomé, Togo. ${ }^{3}$ Department of Dermatology, University Teaching Hospital of Kara, Kara, Togo. ${ }^{4}$ University of Lomé, BP 1515, Lomé, Togo.}

\section{Acknowledgements}

We would like to thank Dr. Landoh, MD, MPH for reviewing and copyediting the manuscript.

\section{Competing interests \\ The authors declare that they have no competing interests.}

Availability of data and materials

Extracted data are with the authors and available for sharing on request.

Consent for publication

Not applicable.

\section{Ethics approval and consent to participate}

This study received approval from the head of the laboratory department to be conducted. Since it was counting records, patient consent was not required. However during the counting and data collection patient names were not collected in order to preserve confidentiality. This study was approved by the head of the laboratory department of the Sylvanus Olympio University Hospital (Ref $N^{\circ}$ 08/2017/LAP/CHUSO)

Funding

Not applicable.

\section{Publisher's Note}

Springer Nature remains neutral with regard to jurisdictional claims in published maps and institutional affiliations.

Received: 4 August 2018 Accepted: 10 September 2018

Published online: 14 September 2018

\section{References}

1. Coremans-Pelseneer J. Epidemiology of Basidiobolomycosis. Ann Soc Belg Med Trop. 1972;52:315-28.

2. Kombaté K, Saka B, Mouhari-Toure A, Akakpo S, Djadou KE, Darré T, et al. Basidiobolomycosis: a review. Med Sante Trop. 2012;22(2):145-52.

3. Almoosa Z, Alsuhaibani M, AlDandan S, Alshahrani D. Pediatric gastrointestinal Basidiobolomycosis mimicking malignancy. Med Mycol Case Rep. 2017;18:31-3

4. Pasha TM, Leighton JA, Smilack JD, Heppell J, Colby TV, Kaufman L. Basidiobolomycosis: an unusual fungal infection mimicking inflammatory bowel disease. Gastroenterology. 1997;112(1):250-4.

5. Saka B, Gnassingbe W, Mahamadou G, Akakpo S, Teclessou J, AbilogunChokki A, et al. Basidiobolomycosis simulating a Mycobacterium ulcerans infection in a Togolese rural child. Case Rep Dermatol Med. 2017;2017:6905783. https://doi.org/10.1155/2017/6905783.

6. Brun LVC, Roux JJ, Sopoh GE, Aguiar J, Eddyani M, Meyers WM, et al. Subcutaneous granulomatous inflammation due to Basidiobolomycosis: case reports of 3 patients in buruli ulcer endemic areas in Benin. Case Rep Pathol. 2018;2018:1351694. https://doi.org/10.1155/2018/1351694.

7. Sackey A, Ghartey N, Gyasi R. Subcutaneous Basidiobolomycosis: a case report. Ghana Med J. 2017;51(1):43-6.

8. Saka B, Kombaté K, Mouhari-Toure A, Akakpo S, Tchangaï B, Amégbor K, et al. Probable Basidiobolomycosis in a Togolese rural young successfully treated with ketoconazole. Bull Soc Pathol Exot. 2010;103(5):293-5.

9. Atadokpédé F, Gnossikè J, Adégbidi H, Dégboé B, Sissinto-Savi de Tovè Y, Adéyé $A$, et al. Cutaneous Basidiobolomycosis: seven cases in southern Benin. Ann Dermatol Venereol. 2017;144(4):250-4. 
10. Cazorla A, Grenouillet F, Piton G, Faure É, Delabrousse É, Mathieu P, et al. A letal case of gastro-intestinal Basidiobolomycosis. Ann Pathol. 2014;34(3):228-32.

11. Sivaraman, Thappa DM, Karthikeyan, Hemanthkumar. Subcutaneous phycomycosis mimicking synovial sarcoma. Int J Dermatol. 1999;38(12):920-3.

12. Bittencourt AL, Serra G, Sadigursky M, Araujo MG, Campos MC, Sampaio LC. Subcutaneous zygomycosis caused by Basidiobolus haptosporus: presentation of a case mimicking Burkitt's lymphoma. Am J Trop Med Hyg. 1982;31(2):370-3.

13. Darré T, Saka B, Mouhari-Toure A, Tchaou M, Dorkenoo AM, Doh K, et al. Mycetoma in the Togolese: an Update from a Single-Center Experience. Mycopathologia. 2018. https://doi.org/10.1007/s11046-018-0260-y.

14. El-Shabrawi MH, Kamal NM, Kaerger K, Voigt K. Diagnosis of gastrointestinal Basidiobolomycosis: a mini-review. Mycoses. 2014;57(Suppl 3):138-43.

15. Clemmensen OJ, Hagdrup H. Splendore-Hoeppli phenomenon in Pityrosporum folliculitis (pseudoactinomycosis of the skin). J Cutan Pathol. 1991;18(4):293-7.

16. Al Jarie A, Al Azraki T, Al Mohsen I, Al Jumaah S, Almutawa A, Mohd Fahim Y, Al Shehri M, Abu Dayah A, Ibrahim A, Maw Shabana M, Rezk Abd-Elwahed Hussein M. Basidiobolomycosis: case series. J Mycol Med. 2011;21(1):37-45.

17. Khot PD, Fredrick DN. PCR-based diagnosis of human fungal infections. Expert Rev Anti Infect Ther. 2009;7(10):1201-21.
18. Chaturvedi VP, Randhawa HS, Khan ZU, Singh N, Kini S. Prevalence of BasidiobolusranarumEidam in the intestinaltract of an insectivorousbat, RhinopomahardwickeihardwickeiGray, Delhi. Sabouraudia. 1984;22(3):185-9.

19. Verma RK, Shivaprakash MR, Shanker A, Panda NK. Subcutaneous zygomycosis of the cervicotemporal region: Due to Basidiobolus ranaram. Med Mycol Case Rep. 2012;1(1):59-62.

20. Ramesh V, Ramam M, Capoor MR, Sugandhan S, Dhawan J, Khanna G. Subcutaneous zygomycosis: report of 10 cases from two institutions in North India. J Eur Acad Dermatol Venereol. 2010;24:1220-5.

21. Krishnan SG, Sentamilsevi G, Kamalam A, Das KA, Janaki C. Entomophthoromycosis in India: a 4-year study. Mycoses. 1998;41:55-8.

22. Rodrigues O, Commey JO. Basidiobolomycosis in Ghanaian children. Trop Doct. 1994;24(4):170-1.

23. Madke B, Chikhalkar S, Mahajan S, Kharkar V, Khopkar U. Ulcerative subcutaneous zygomycosis: developement of hypothyroidism induced by potassium iodide (Wolff-Chaikoff effects). Indian J Dermatol Venereol Leprol. 2010;76:431-3.

24. Khan ZU, Parkash B, Kapoor M, Medda JP, Chandy R. Basidiobolomycosis of the rectum masquerading as Crohn's disease. Clin Infect Dis. 1998;26:521-3.

25. Kabra SK, Jain Y, Sudhin T, Iver KV, Ninan SA, Seth V. Successful treatment of entomophthoromycosis with itraconazole. Indian Pediatr. 1998:35:163-6.
Ready to submit your research? Choose BMC and benefit from:

- fast, convenient online submission

- thorough peer review by experienced researchers in your field

- rapid publication on acceptance

- support for research data, including large and complex data types

- gold Open Access which fosters wider collaboration and increased citations

- maximum visibility for your research: over 100M website views per year

At BMC, research is always in progress.

Learn more biomedcentral.com/submissions 